\title{
ARIDITY IN EQUATORIAL AFRICA DURING THE LAST 225,000 YEARS: A RECORD OF OPAL PHYTOLITHS/FRESHWATER DIATOMS FROM THE ZAIRE (CONGO) DEEP-SEA FAN (NORTHEAST ANGOLA BASIN)
}

\author{
J H F JANSEN*, C ALDERLIESTEN**, C M HOUSTON** \\ A F M DE JONG**, K VAN DER BORG** and J M VAN IPEREN*
}

ABSTRACT. Maps of accumulation rates of freshwater diatoms and opal phytoliths in the surface sediments of the Zaire fan show that both types of microfossils were supplied to the ocean floor by the Zaire River, and that opal phytoliths also have a southern source, probably the region of the Namibian desert. The PhFD ratio, of opal phytoliths to freshwater diatoms, can be regarded as an aridity index for equatorial Africa, and probably for large parts of the central and southern Atlantic. In two cores, the record of the PhFD ratio indicates humidity ca 225-190 ka BP, aridity 190-135 ka BP with maxima ca 170 and $140 \mathrm{ka}$ BP and a humid excursion $150 \mathrm{ka} \mathrm{BP}$, an increase in humidity $115 \mathrm{ka} \mathrm{BP}$, a less humid period $90-30 \mathrm{ka} \mathrm{BP}$, more humidity ca $30-17 \mathrm{ka}$ BP with possibly more arid intervals ca 22.5 and $20 \mathrm{ka}$ BP. In general, glacial (sub) stages were more arid and interglacial (sub) stages more humid. For the last 20 $\mathrm{ka}$, the PhFD ratio corresponds closely with the known climatic events in tropical Africa.

\section{INTRODUCTION}

Information stored in sedimentary and other rocks is often measured in the form of ratios of a single parameter to one or more other quantities; eg, 1) numbers of species or groups of microfossils in relation to a larger group, 2) bulk concentrations of chemical or mineralogic components, or 3) physical properties such as grain-size parameters. Such a parameter depends greatly on the quantities in the denominator that are often irrelevant to the processes to be studied and are controlled by other phenomena. For this reason, there is a need for making the parameters independent. This can be done by conversion of the contents or concentrations into accumulation rates, in which case accurate dates are required. In this paper, we give an example of the advantage of the calculation of accumulation rates based on counts of opal phytoliths and frustules of freshwater diatoms in deep-sea cores.

Opal phytoliths are siliceous clasts from leaves of vascular plants, mainly grasses (Baker, 1960; Bukry, 1980), and diatoms are photosynthetic single-celled algae that produce siliceous frustules. Both types of microfossils are derived from land areas. In marine sediments, consequently, they may be interpreted as signals of climate on the neighboring continent. Freshwater diatoms may reflect river influx from humid regions as well as wind-borne transport out of arid regions (Hustedt, 1921, in Kolbe, 1957; Delaney et al, 1967; Folger, 1970; Parmenter \& Folger, 1974; Melia, 1984; Pokras \& Mix, 1985; Stabell, 1986; Gasse et al, 1989), while opal phytoliths are usually considered to be transported by wind (Folger, 1970; Parmenter \& Folger, 1974; Bukry, 1980; Melia, 1984; Pokras \& Mix, 1985; Stabell, 1986).

We report the significance of the freshwater diatoms and opal phytoliths in surface sediments of the Zaire (Congo) deep-sea fan (eastern

\footnotetext{
${ }^{*}$ Netherlands Institute for Sea Research, P O Box 59, 1790 AB Den Burg, Texel, The Netherlands

*** Robert J van de Graaff Laboratorium, Rijksuniversiteit, P O Box 80000 ,

3508 TA Utrecht, The Netherlands
} 
equatorial Atlantic Ocean), a region with a strong terrigenous sediment input (Jansen et al, 1984; van der Gaast \& Jansen, 1984; Eisma \& Kalf, 1984; van Weering \& van Iperen, 1984; Jansen, 1985; Jansen, Kuijpers \& Troelstra, 1986). Further, the inferences from the surface sediments were applied to the contents of two hemipelagic cores that represent the last 225,000 years on the geological time scale in the region.

\section{MATERIAL AND METHODS}

The sediments of the Zaire fan are siliceous oozes with an inorganic component that consists mainly of terrigenous clay minerals (Jansen et al, 1984; van der Gaast \& Jansen, 1984; Jansen 1985). The surface sediments can be roughly divided into fine-grained turbidites in the central fan area

\section{TABLE 1}

Locations, corrected water depth and mass accumulation rates (MAR) on carbonate-free basis for top intervals of 25 cores from the Zaire deep-sea fan. Age control is based on carbonate stratigraphy $(\mathrm{Ca})$, microfossils $(\mathrm{M})$, oxygen isotopes $(\mathrm{O})$, ${ }^{14} \mathrm{C}$ dating $(\mathrm{C})$ and ${ }^{230} \mathrm{Th}$-excess dating $(\mathrm{T})$.

\begin{tabular}{|c|c|c|c|c|c|}
\hline Core & Lat & Long & $\begin{array}{c}\text { Water } \\
\text { depth } \\
\text { (m) }\end{array}$ & $\underset{\left(\mathrm{g} \cdot \mathrm{cm}^{-2} \cdot \mathrm{ka}^{-1)}\right.}{\operatorname{MAR}}$ & $\begin{array}{l}\text { Age } \\
\text { control }\end{array}$ \\
\hline T78-26 & $6^{\circ} 05.0^{\prime} \mathrm{S}$ & $11^{\circ} 16.6^{\prime} \mathrm{E}$ & 605 & 22 & $\mathrm{Ca}, \mathrm{M}, \mathrm{C}$ \\
\hline T78-27 & $5^{\circ} 52.5^{\prime} \mathrm{S}$ & $10^{\circ} 59.9^{\prime} \mathrm{E}$ & 1450 & 22 & $\mathrm{Ca}$ \\
\hline T78-28 & $6^{\circ} 00.0^{\prime} \mathrm{S}$ & $10^{\circ} 43.0^{\prime} \mathrm{E}$ & 1940 & 18 & $\mathrm{Ca}, \mathrm{C}$ \\
\hline T78-29 & $5^{\circ} 59.0^{\prime} \mathrm{S}$ & $10^{\circ} 24.8^{\prime} \mathrm{E}$ & 2310 & 16 & $\mathrm{Ca}, \mathrm{C}$ \\
\hline T78-30 & $5^{\circ} 59.6^{\prime} \mathrm{S}$ & $9^{\circ} 56.6^{\prime} \mathrm{E}$ & 3040 & $>29$ & $\mathrm{C}$ \\
\hline T78-33 & $5^{\circ} 11.0^{\prime} \mathrm{S}$ & $7^{\circ} 58.0^{\prime} \mathrm{E}$ & 4120 & 1.6 & $\mathrm{Ca}, \mathrm{M}, \mathrm{C}$ \\
\hline T78-34 & $6^{\circ} 49.5^{\prime} \mathrm{S}$ & $7^{\circ} 47.7^{\prime} \mathrm{E}$ & 4270 & $>2$ & $\mathrm{Ca}, \mathrm{C}$ \\
\hline T78-35 & $6^{\circ} 13.7^{\prime} \mathrm{S}$ & $6^{\circ} 41.7^{\prime} \mathrm{E}$ & 4560 & 1.0 & $\mathrm{C}$ \\
\hline T78-36 & $7^{\circ} 35.2^{\prime} \mathrm{S}$ & $6^{\circ} 29.5^{\prime} \mathrm{E}$ & 4980 & 0.27 & $\mathrm{Ca}, \mathrm{C}$ \\
\hline T78-37 & $8^{\circ} 15.5^{\prime} \mathrm{S}$ & $5^{\circ} 27.4^{\prime} \mathrm{E}$ & 5060 & 0.7 & $\mathrm{Ca}$ \\
\hline T78-38 & $8^{\circ} 51.2^{\prime} \mathrm{S}$ & $4^{\circ} 23.7^{\prime} \mathrm{E}$ & 5490 & 0.21 & $\mathrm{Ca}, \mathrm{M}, \mathrm{T}$ \\
\hline T78-39 & $8^{\circ} 49.7^{\prime} \mathrm{S}$ & $6^{\circ} 01.9^{\prime} \mathrm{E}$ & 5070 & 2.0 & $\mathrm{Ca}, \mathrm{C}$ \\
\hline T78-41 & $8^{\circ} 45.1^{\prime} \mathrm{S}$ & $7^{\circ} 08.1^{\prime} \mathrm{E}$ & 4810 & 0.4 & $\mathrm{Ca}, \mathrm{C}$ \\
\hline T78-42 & $8^{\circ} 36.4^{\prime} \mathrm{S}$ & $8^{\circ} 47.8^{\prime} \mathrm{E}$ & 4470 & 0.50 & $\mathrm{Ca}, \mathrm{C}$ \\
\hline T78-43 & $8^{\circ} 23.4^{\prime} \mathrm{S}$ & $9^{\circ} 25.0^{\prime} \mathrm{E}$ & 4300 & 0.7 & $\mathrm{Ca}$ \\
\hline T78-45 & $7^{\circ} 47.8^{\prime} \mathrm{S}$ & $10^{\circ} 07.0^{\prime} \mathrm{E}$ & 4070 & 1.2 & $\mathrm{Ca}, \mathrm{M}, \mathrm{C}$ \\
\hline T78-46 & $6^{\circ} 50.1^{\prime} \mathrm{S}$ & $10^{\circ} 45.3^{\prime} \mathrm{E}$ & 2100 & 7.6 & $\mathrm{Ca}, \mathrm{M}, \mathrm{O}, \mathrm{C}$ \\
\hline T78-49 & $3^{\circ} 57.8^{\prime} \mathrm{S}$ & $8^{\circ} 03.7^{\prime} \mathrm{E}$ & 4340 & 2.0 & $\mathrm{Ca}, \mathrm{M}, \mathrm{C}$ \\
\hline T80-3 & $3^{\circ} 14.5^{\prime} \mathrm{S}$ & $2^{\circ} 23.6^{\prime} \mathrm{E}$ & 4369 & ca 0.4 & $\mathrm{Ca}, \mathrm{C}$ \\
\hline T80-4 & $6^{\circ} 08.4^{\prime} \mathrm{S}$ & $5^{\circ} 01.9^{\prime} \mathrm{E}$ & 5059 & 4.2 & $\mathrm{Ca}, \mathrm{M}, \mathrm{C}$ \\
\hline T80-6 & $8^{\circ} 00.2^{\prime} \mathrm{S}$ & $7^{\circ} 59.3^{\prime} \mathrm{E}$ & 4457 & 0.8 & $\mathrm{Ca}, \mathrm{C}$ \\
\hline T80-7 & $7^{\circ} 00.0^{\prime} \mathrm{S}$ & $9^{\circ} 01.9^{\prime} \mathrm{E}$ & 3946 & 1.6 & $\mathrm{Ca}, \mathrm{C}$ \\
\hline T80-8 & $6^{\circ} 48.3^{\prime} \mathrm{S}$ & $9^{\circ} 52.8^{\prime} \mathrm{E}$ & 3678 & 2.9 & $\mathrm{Ca}, \mathrm{C}$ \\
\hline T80-10 & $6^{\circ} 13.1^{\prime} \mathrm{S}$ & $10^{\circ} 34.5^{\prime} \mathrm{E}$ & 1988 & 7.4 & $\mathrm{Ca}, \mathrm{M}, \mathrm{C}$ \\
\hline T80-20 & $12^{\circ} 08.6^{\prime} \mathrm{S}$ & $9^{\circ} 18.8^{\prime} \mathrm{E}$ & 4460 & ca 2.0 & $\mathrm{C}$ \\
\hline
\end{tabular}


AMS ${ }^{14} \mathrm{C}$ ages for piston cores from the Zaire fan. See Table 1 for locations.

\begin{tabular}{|c|c|c|c|}
\hline Core & $\begin{array}{l}\text { Depth in } \\
\text { core }(\mathrm{cm})\end{array}$ & ${ }^{14} \mathrm{C}$ age & Sample no. \\
\hline T78-28 & 13 & $1800 \pm 300$ & Utc- 539 \\
\hline T78-28 & 60 & $2800 \pm 120$ & -540 \\
\hline T78-29 & 7 & $990 \pm 100$ & -444 \\
\hline T78-29 & 55 & $1760 \pm 100$ & -443 \\
\hline T78-30 & 17 & $9640 \pm 180$ & -459 \\
\hline T78-33 & 274 & $27,300 \pm 700$ & -315 \\
\hline T78-33 & 275 & $\begin{array}{r}31,100+1200 \\
-1100\end{array}$ & -436 \\
\hline T78-33 & 313 & $\begin{array}{r}37,000+3000 \\
-2000\end{array}$ & -224 \\
\hline T78-33 & 316 & $\begin{array}{r}30,400+1100 \\
-1000\end{array}$ & -435 \\
\hline T78-34 & 71 & $6500 \pm 90$ & -542 \\
\hline T78-35 & 56 & $10,100 \pm 200$ & -460 \\
\hline $\mathrm{T} 78-36$ & 8 & $9800 \pm 200$ & -457 \\
\hline T78-39 & 40 & $5620 \pm 170$ & -458 \\
\hline $\mathrm{T} 78-41$ & 3 & $12,060 \pm 140$ & -445 \\
\hline$T 78-45$ & 313 & $27,800 \pm 800$ & -316 \\
\hline$T 78-45$ & 371 & $\begin{array}{r}38,000+3000 \\
-2000\end{array}$ & -317 \\
\hline$T 78-46$ & 987 & $\begin{array}{r}37,000+4000 \\
-2000\end{array}$ & -434 \\
\hline$T 78-46$ & 1068 & $\begin{array}{r}37,000+3000 \\
-2000\end{array}$ & -318 \\
\hline T78-46 & 1069 & $\begin{array}{r}42,000+9000 \\
-4000\end{array}$ & -433 \\
\hline T78-49 & 253 & $\begin{array}{r}26,700 \pm 700 \\
-600\end{array}$ & -225 \\
\hline T78-49 & 369 & $>45,000$ & -227 \\
\hline T80-3 & 3 & $4500 \pm 120$ & -465 \\
\hline T80-3 & 18 & $12,700 \pm 300$ & -464 \\
\hline T80-3 & 42 & $13,000 \pm 200$ & -463 \\
\hline T80-4 & 159 & $10,930 \pm 120$ & -321 \\
\hline T80-4 & 307 & $\begin{array}{r}39,000+8000 \\
-4000\end{array}$ & -467 \\
\hline T80-6 & 131 & $\begin{array}{r}34,200+1800 \\
-1500\end{array}$ & -322 \\
\hline T80-10 & 278 & $15,000 \pm 200$ & -560 \\
\hline T80-10 & 314 & $18,000 \pm 400$ & -456 \\
\hline T80-10 & 454 & $25,700 \pm 700$ & -455 \\
\hline $\mathrm{T} 80-10$ & 768 & $\begin{array}{r}45,000+9000 \\
-5000\end{array}$ & -320 \\
\hline T80-10 & 982 & $>45,000$ & -319 \\
\hline T80-11 & 4 & $8120 \pm 130$ & -561 \\
\hline T80-11 & 43 & $920 \pm 130$ & -562 \\
\hline T80-20 & 8 & $4850 \pm 140$ & -466 \\
\hline T80-20 & 43 & $\begin{array}{r}32,700+1300 \\
-1100\end{array}$ & -537 \\
\hline T80-20 & 78 & $27,900 \pm 800$ & -538 \\
\hline
\end{tabular}


and hemipelagic and pelagic deposits in the outer fan and on the continental slope (Jansen et al, 1984; van Weering \& van Iperen, 1984). The stratigraphy of the two cores, T78-33 and T78-46, is based on calcium carbonate concentrations (Jansen et al, 1984; Jansen, 1985), oxygen-isotope data (Olausson, 1984), on studies of calcareous microfossils (Zachariasse, Schmidt \& van Leeuwen, 1984; van Leeuwen, 1988) and siliceous microfossils (Mikkelsen, 1984; Bjørklund \& Jansen, 1984; de Ruiter \& Jansen, 1985; Jansen \& van Iperen, ms in preparation) and on ${ }^{14} \mathrm{C}$ dates (Jansen et $a l, 1984,1987)$. Time resolution can be substantially improved by employing the Utrecht tandem accelerator for mass-spectrometric (AMS) ${ }^{14} \mathrm{C}$ measurements for milligram-size samples. Previously, the low carbonate concentrations of the sediments required large samples of $20 \mathrm{~cm}$ or more, or organic carbon had to be dated (Jansen et al, 1984), the results of which were not accurate enough for the purpose of this study. For calculations of mass accumulation rates of surface sediments, the $\mathrm{H}_{2} \mathrm{O}$ content of the coretop samples were measured along with additional ${ }^{14} \mathrm{C}$ dates (Tables 1,2 ).

Carbon samples were prepared by treating sediment material with $4 \%$ $\mathrm{HCl}$ to form at least $1 \mathrm{ml}$ of $\mathrm{CO}_{2}(\mathrm{STP})$, which was converted into graphite by reduction with finely divided iron powder in the presence of excess hydrogen (Hut, Östlund \& van der Borg, 1986). The mixture of iron and graphite $(2: 1)$ is pressed into a $2 \mathrm{~mm}$ diameter hole of an aluminum holder. The ${ }^{14} \mathrm{C}$ measurements were made in separate runs with the Utrecht tandem accelerator (van der Borg et al, 1987).

The opal phytolith and diatom data were derived from van Iperen $e t$ al (1987) and Jansen and van Iperen ( $m s$ in preparation).

\section{ORIGIN OF THE OPAL PHYTOLITHS AND FRESHWATER DIATOMS}

The measurements of freshwater diatoms and opal phytoliths in surface sediments form part of a diatom study on surface sediments of the Zaire fan region. The original distribution patterns were based on ratios in relation to the numbers of marine diatoms (Figs 1,2). These maps indicate different sources for the freshwater diatoms and the phytoliths. Basically, rivers and wind are the two possible modes of transport of terrigenous material to the tropical ocean. Figure 1, showing a freshwater-diatom concentration near the Zaire River mouth, suggests that these microfossils were supplied from the drainage area of the Zaire River and that turbidity distributed them through the Zaire canyon to the deep-sea fan, over $800 \mathrm{~m}$ away from the river mouth. The phytolith distribution (Fig 2), with maximum values at ca $700 \mathrm{~km}$ offshore, suggests a southern source (van Iperen et al, 1987), probably the region of the Namibian desert, and subsequent eolian transport by the southeast trade winds up to the fan region.

The patterns of both maps, however, are biased by the abundances of marine diatoms which form the denominators of the mapped fractions. These diatoms reflect the diatom productivity in the ocean surface waters (van Iperen et al, 1987) and are irrelevant to continental climatic processes. The data become more evident when the ratios are converted to independent accumulation rates (Figs 3,4). Then the maps indicate even more 


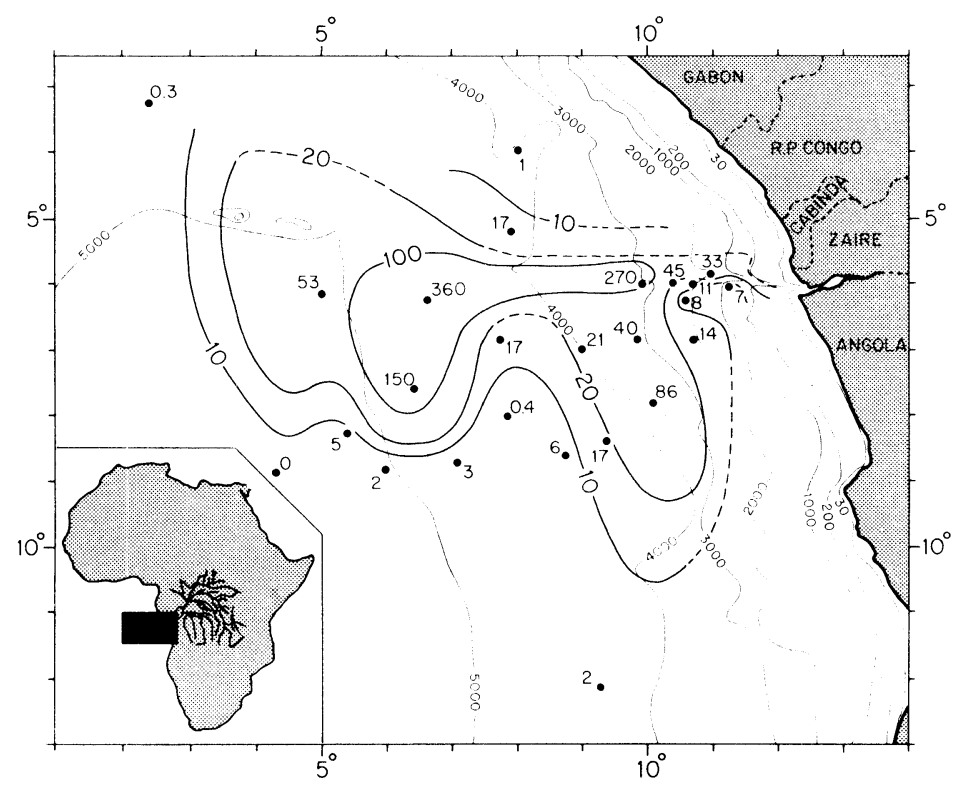

Fig 1.Ratios of freshwater diatoms to marine diatoms $(\times 100)$ in surface sediments of the Zaire fan region (after van Iperen et al, 1987)

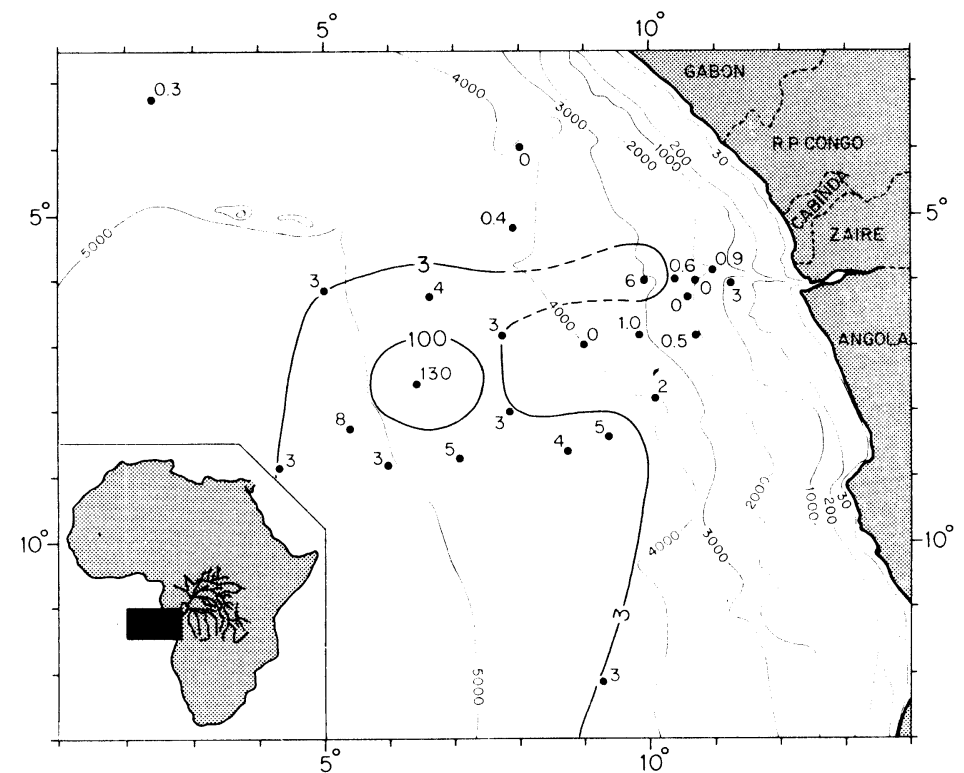

Fig 2. Ratios of opal phytoliths to marine diatoms $(\times 100)$ in surface sediments of the Zaire fan region (after van Iperen et al, 1987) 


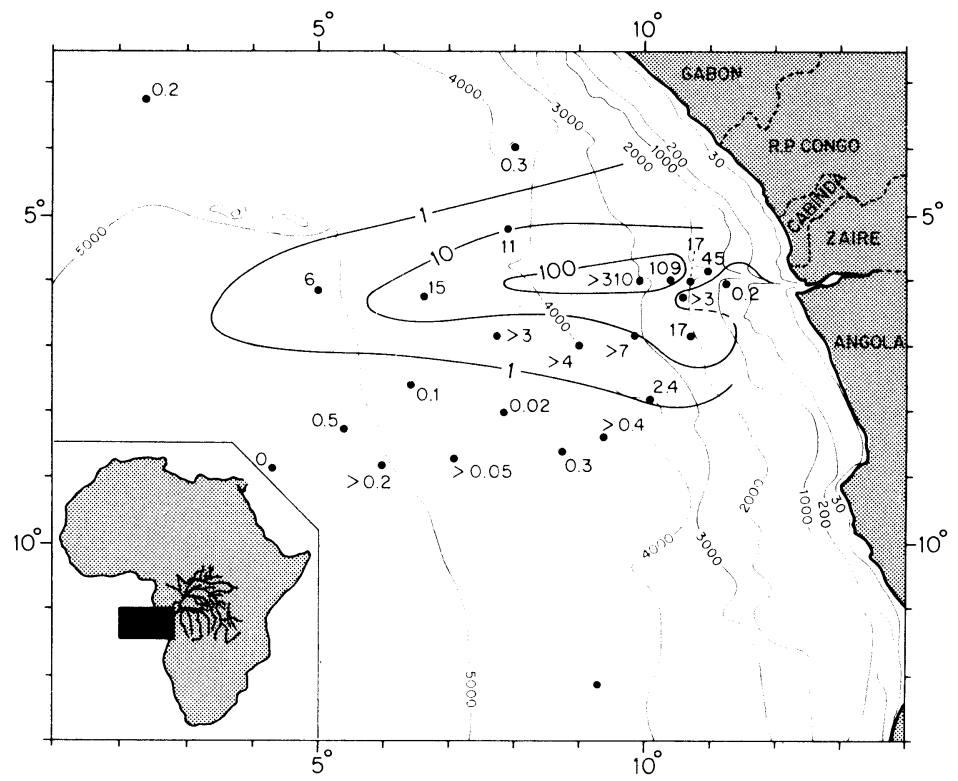

Fig 3. Accumulation rates of freshwater diatoms $\left(10^{6} \mathrm{~cm}^{-2} \mathrm{ky}^{-1}\right)$ in surface sediments of the Zaire fan region

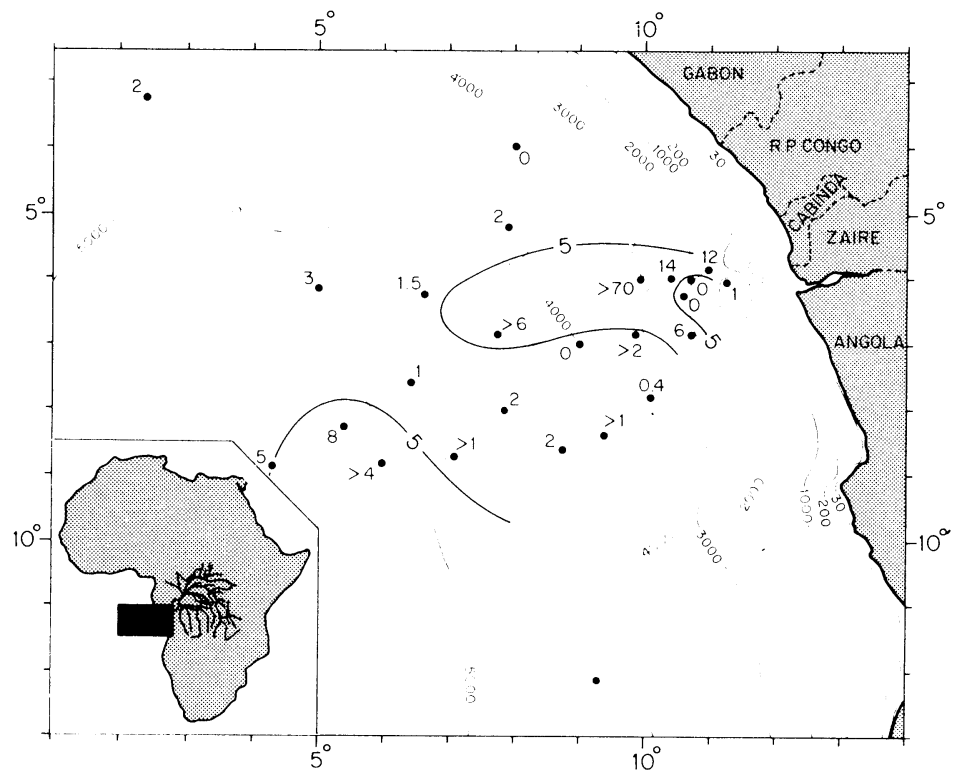

Fig 4. Accumulation rates of opal phytoliths $\left(10^{5} \mathrm{~cm}^{-2} \mathrm{ky}^{-1}\right)$ in surface sediments of the Zaire fan region 


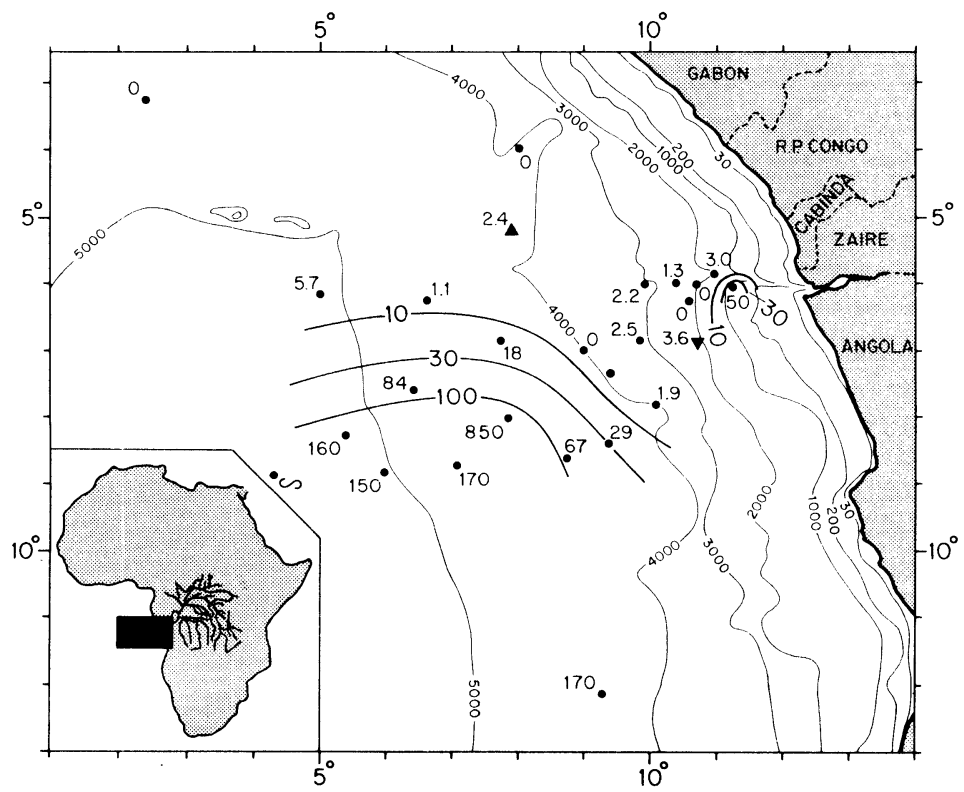

Fig 5. PhFD ratios (opal phytoliths to freshwater diatoms) $(\times 100)$ in surface sediments of the Zaire fan region and locations of the cores T78-33 ( $\mathbf{\Delta})$ and T78-46 (v)

clearly that the freshwater diatoms were indeed supplied by fluvial transport. The opal phytoliths, however, appear to be distributed around two concentrations, one in front of the Zaire River mouth and one in the south. The highest ratio in Figure 2, which is due to a very low marine diatom contribution, occurs in the zone of the lowest phytolith accumulation rates in Figure 4 . The binary distribution demonstrates that the opal phytoliths in the study area are not only of southern eolian origin but came also from the Zaire drainage area together with the freshwater diatoms.

Because the phytoliths have an important eolian source in contrast to the freshwater diatoms, we introduced a new parameter, the ratio of opal phytoliths to freshwater diatoms (PhFD ratio), and questioned whether it can be regarded as an aridity index. The ratio is ca $50 \%$ in the zone that separates the fluvial and eolian phytolith concentrations (Fig 5). Therefore, if the $\mathrm{PhFD}$ ratio is over $50 \%$, a considerable eolian influence can be inferred for the Zaire fan region.

\section{THE CLIMATE RECORD OVER THE LAST 225,000 YEARS}

In order to test whether the PhFD ratio can also be applied as an aridity index in the sedimentary record, two piston cores from the Zaire fan were investigated. We selected core T78-46 for its high accumulation rates, which provides a good time-resolution, and core T78-33, with a lower accumulation rate, which represents a longer time span (Figs 6 and 7). Although the two locations, outside the southern eolian phytolith concentration, caused 


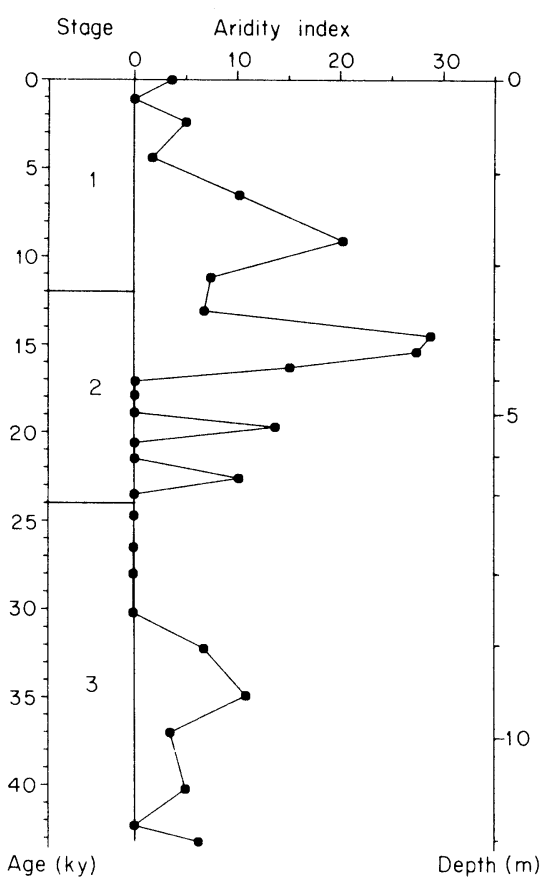

Fig 6. Aridity indexes (ratios of opal phytoliths to freshwater diatoms, $\times 100)$ and stratigraphy for core T78-46 from the Zaire deep-sea fan (linear time scale, length $1112 \mathrm{~cm}$ ). Numbers to the left indicate oxygen-isotope stages (Olausson, 1984). See Fig 5 and Table 1 for location.

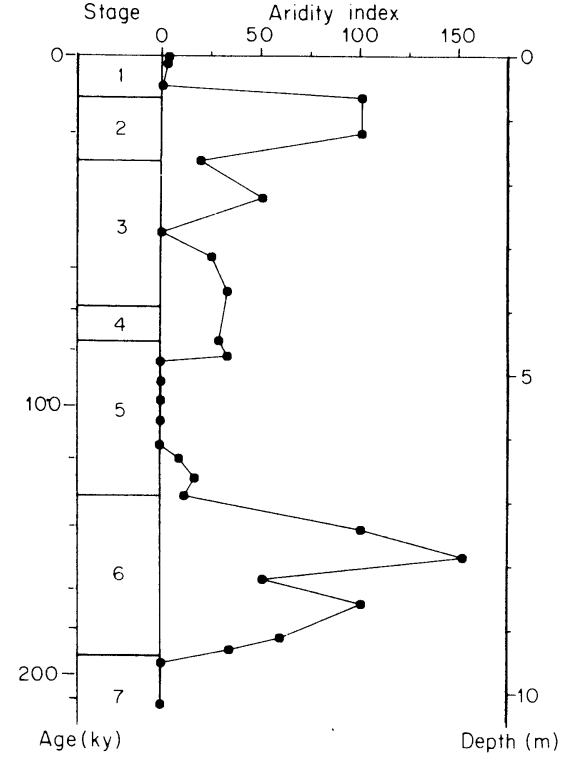

Fig 7. Aridity indexes (ratios of opal phytoliths to freshwater diatoms, $\times 100)$ and stratigraphy for core T78-33 from the Zaire deep-sea fan (linear depth scale, length $1027 \mathrm{~cm}$ ). Numbers to the left indicate calcium carbonate stages which approximately match the oxygenisotope stages (Jansen et al, 1984; Jansen, 1985). See Fig 5 and Table 1 for location.

rather low PhFD ratios (Fig 5), the downcore record nevertheless appeared to contain relevant climatic information.

The Period After 30,000 BP. The most conspicuous features in the PhFD record of core T78-46 (Fig 6) are correlated with well-known climatic events in tropical Africa. The period ca 19,000-13,000 BP was marked by strong aridity in R P Congo, around Lake Victoria and Lake Tanganyika, at Mt Kenya, and in the Rwanda and Burundi highlands. The climate became more humid ca $13,000 \mathrm{BP}$ with a maximum humidity ca $12,000 \mathrm{BP}$. There was a dry interlude at or just before 10,000 BP which preceded a strong "postglacial" increase in precipitation that took place ca 9000 BP (Kendall, 1969; Peyrot \& Lanfranchi, 1984; Bonnefille \& Riolet, 1988; Tiercelin et al, 1988; van Zinderen Bakker \& Coetzee, 1988). These events were also recorded in more remote places like the Chad Basin, the Afar and Ethiopian Rift Lakes and the Kalahari region, and were common in the African tropics (Servant \& Servant-Vildary, 1980; Gasse, Rognon \& Street, 1980; Hamilton, 1982; van Zinderen Bakker, 1983; Rognon, 1987; van Zinderen Bakker \& Coetzee, 1988). 
Evidence concerning the African climate prior to ca 20,000 BP is rather scarce. From ca $40,000-20,000 \mathrm{BP}$, it was generally humid in western equatorial and tropical Africa (Gasse et al, 1989), which agrees with the PhFD data of core T78-46. In more detail, these data show evidence of more dryness before ca 30,000 and a shift to more humid conditions around that time. This shift is also observed in east and central Africa, where until ca 27,000 BP the climate was even slightly wetter and warmer than today (Hamilton, 1982; van Zinderen Bakker, 1983; Casanova et al, 1988; van Zinderen Bakker \& Coetzee, 1988). Bonnefille and Riolet (1988), seemingly in contradiction, described an increase in aridity ca 30,000 BP in the Burundi highlands. The chronology of the older part of their core, however, is liable to considerable uncertainties of the ${ }^{14} \mathrm{C}$ dates. Depending on the interpretation of these dates, the dessication can be placed within the time interval 38,000-27,000 BP or even somewhat later, which neither contradicts nor corroborates the humidification ca 30,000 BP. Further away, in Namibia precipitation increased between 28,000 and 25,000 BP (van Zinderen Bakker, 1983), and in the Nigero-Chadian Sahel and in Lake Abhé (Ethiopia) a more humid phase began ca 30,000-29,000 BP (Servant \& Servant-Vildary, 1980; Gasse, Rognon \& Street, 1980; Durand \& Lang, 1986).

The high PhFD ratios at ca 22,500 and 20,000 BP in core T78-46 are possibly of little significance because both values depend on a single sample. They may, however, mirror the arid maxima just before and after 21,500 BP in Burundi (Bonnefille \& Riolet, 1988), decreased rainfall in Namibia between 23,000 and 19,000 BP (van Zinderen Bakker, 1983) and, perhaps, also the decrease in precipitation that took place in the Sahelian zone and the Ziway-Shala Basin (Ethiopia) ca 22,000 BP (Gasse, Rognon \& Street, 1980; Durand \& Lange, 1986).

The above brief review demonstrates that the PhFD ratios in T78-46 match the known climatic events in equatorial Africa. This agreement, however, does not imply a direct causal relation. There are at least two possible explanations. First, a decrease in precipitation in the Zaire River drainage area may cause a decrease in diatom productivity in inland water and, subsequently, a reduced influx in the marine sediment resulting in an enlarged PhFD ratio. Secondly, a larger PhFD ratio may also mirror an increased wind intensity. During glacial periods, the westerlies strengthened and expanded northward, the continental anticyclone became compressed, and stronger wind prevailed over southern Africa (Tyson, 1986) carrying the Namibian dust further northward. It is evident that the PhFD ratio contains both messages: precipitation in the Zaire River system and strength of transporting wind. The agreement of the record of core T78-46 with the aridity events of the last 30,000 years, however, indicates that the ratio anyway mirrors aridity in the equatorial tropics, either in a direct or an indirect manner. This allows us to apply the PhFD ratio in the Zaire fan region as an index of paleo-aridity in equatorial Africa.

The Period Before 30,000 BP. The upper $330 \mathrm{~cm}$ of the $\mathrm{PhFD}$ record of core T78-33 (Fig 7) can be regarded as a less detailed version of the record of T78-46. In the older lower and middle parts of the core, the PhFD ratio is low in the lowest $50 \mathrm{~cm}$, suggesting humidity between ca 225,000 and 
$190,000 \mathrm{BP}$. It is highest in carbonate stage 6 which approximately represents the oxygen isotope stage 6 (Jansen et al, 1984; Jansen, 1985) of 190,000 - 130,000 yr ago (Martinson et al, 1987). The peaks of maximum aridity occurred in the interstadial phases ca 170,000 and 140,000 BP, interrupted by a more humid interval ca $150,000 \mathrm{BP}$. The most humid period is indicated in stage 5 between ca 120,000 and 90,000 BP. The PhFD curve responds reasonably to the few data known to us that deal with the African continental climate before 40,000 BP. Large saline lakes existed in the Sahara region at ca 150,000,130,000 and 100,000 yr ago (Butzer et al, 1972; Causse et al, 1988; Gasse et al, 1989). The period from ca $80,000-30,000$ BP was generally somewhat moister than during the following "glacial" maximum in southern Africa (Klein, 1986), and was humid in R P Congo (Peyrot \& Lanfranchi, 1984). In R P Congo, there was an arid interruption ca 60,000 $50,000 \mathrm{BP}$, possibly the same aridity as was reported by Durand \& Lang (1986) for the Sahel $(>50,000 \mathrm{BP})$.

\section{DISCUSSION}

In a marine diatom study, Pokras (1987) attributed maxima of the diatom Thalassionema nitzschioides in sediments of the Guinea Basin to periods of high river runoff of the Niger and Zaire Rivers. A dominance of this species, however, may be due more particularly to the input of river nutrients rather than to lowered salinity itself (Pokras \& Molfino, 1986: Factor 3; van Iperen et al, 1987: Group 2; Jansen, 1990). Features in the occurrence of $T$ nitzschioides that seem to accord with the PhFD record are the "humid" peaks at or just prior to the stage $6 / 5$ transition, in substage $5 \mathrm{c}$ $(100,000 \mathrm{BP})$, ca $28,000 \mathrm{BP}$ and in stage 1 , and the "arid" lows of the stage $5 / 4$ transition and at 14,000 BP. If the data by Pokras may be compared with those from the Zaire deep-sea fan, both the river discharge and nutrient fluxes might have been large at these times. In contrast, the "humid" peaks 80,000 and 54,000 BP, and the "arid" lows 116,000 and 97,000 BP, occur in intervals with a high and low aridity index, respectively. This suggests that at these times a relative low river discharge was accompanied with a high nutrient supply $(80,000$ and $54,000 \mathrm{BP})$ and a high river discharge with a low nutrient supply $(116,000$ and $97,000 \mathrm{BP})$.

The origin of opal phytoliths and freshwater diatoms in deep-sea sediments depends greatly on regional environmental conditions. Most published studies attributing the presence of opal phytoliths and freshwater diatoms to predominant wind transport are from the central Atlantic off northwest Africa. There a relatively straight situation exists, because the prevailing wind pattern and the presence of the Sahara exclude a major fluvial contribution. This interpretation is corroborated by observations of opal phytoliths and freshwater diatoms in eolian dust (Ehrenberg, 1854, in Stabell, 1986; Hustedt, 1921, in Kolbe, 1957; Delaney et al, 1967; Folger, 1970; Melia, 1984; Pokras \& Mix, 1985) and by the resemblance of the distribution patterns with the patterns of northwest African pollen and spores in Atlantic sediments (Hooghiemstra, Agwu \& Beug, 1986).

Nevertheless, the observation of large numbers of the freshwater diatom Aulacosira (Melosira) granulata in sediments of the Guinea Basin near the Niger Delta (Melia, 1984) demonstrates that a fluvial contribution 
of freshwater diatoms may not be neglected. The data in Melia (1984) show that the ratios of opal phytoliths to freshwater diatoms in this area are of the same order of magnitude as those in the Zaire fan region, and the distribution patterns in the surface sediments (Melia, 1984, Figs 8 and 10) indicate that particularly the freshwater diatoms have also a fluvial source. If this is true, the PhFD ratio in the east central Atlantic may also be regarded as an aridity indicator, in this case of northwest Africa.

It can be easily understood why phytoliths are more susceptible to eolian transport and freshwater diatoms are more readily supplied by rivers. Phytoliths originate from plants, mainly grasses, and grow on land, whereas freshwater diatoms grow in swamps, lakes and rivers. The diatom $A$ granulata, which dominates the freshwater diatoms in the Zaire fan (van Iperen et al, 1987), the Guinea Basin and the Atlantic off northwest Africa (Melia, 1984; Pokras \& Mix, 1985), is characteristic of the plankton of great African rivers (Gasse et al, 1989). Consequently, in regions where both modes of transport of terrigenous material occur, the PhFD ratio will be a signal of the contribution of wind transport $v s$ fluvial transport, or an aridity index. The data presented and discussed here indicate that this may hold for at least large parts of the southern and central Atlantic Ocean.

\section{ACKNOWLEDGMENTS}

We thank B Verschuur for drawing the figures and an anonymous reviewer of RADIOCARBON for useful comments on an earlier version of the manuscript. The ${ }^{14} \mathrm{C}$ investigations were part of the program of the Foundation for Fundamental Research on Matter (FOM) and were supported in part by the Netherlands Technology Foundation (STW) and the Netherlands Organization for Scientific Research (NWO). The cruises during which the cores were collected were financed by the Netherlands Marine Research Foundation (SOZ).

\section{REFERENCES}

Baker, G, 1960, Fossil opal phytoliths: Micropaleontol, v 6, p 79-85.

Bjørklund, K R and Jansen, J H F, 1984, Radiolaria distribution in Middle and Late Quaternary sediments and palaeoceanography in the eastern Angola Basin: Netherlands Jour Sea Research, v 17, no. 2-4, p 299-312.

Bonnefille, R and Riollet, G, 1988, The Kashiru pollen sequence (Burundi) palaeoclimatic implications for the last 40,000 yr BP in tropical Africa: Quaternary Research, v 30, no. 1, p 19-35.

Bukry, D, 1980, Opal phytoliths from the tropical eastern Pacific Ocean, Deep Sea Drilling Project Leg 54: Initial Repts Deep Sea Drilling Proj, v 54, p 575-589.

Butzer, K W, Isaac, G L, Richardson, J L and Washbourn-Kamau, C, 1972, Radiocarbon dating of East African lake levels: Science, v 175, no. 4026, p 1069-1076.

Casanova, J, Hillaire-Marcel, C, Page, N, Taieb, M and Vincens, A, 1988, Stratigraphie et paléohydrologie des épisodes lacustres du Quaternaire récent du rift Suguta (Kenya): Acad sci [Paris] Comptes Rendus, v 307, ser II, p 1251-1258.

Causse, C, Conrad, G, Fontes, J-C, Gasse, F, Gibert, E and Kassir, A, 1988: Le dernier "humide" pléistocène du Sahara nord-occidental daterait de 80-10000 ans: Acad sci [Paris] Comptes rendus, v 3-6, ser II, p 1459-1464.

Delaney, A C, Delaney, Audrey C, Parkin, D W, Griffin, J J, Goldberg, E D and Reimann, B E F, 1967, Airborne dust collected at Barbados: Geochim et Cosmochim Acta, v 31, p 885-909. 
de Ruiter, R S C and Jansen, J H F, 1985, Two Pleistocene silicoflagellate biohorizons from the Angola Basin (SE Atlantic): Marine Micropaleontol, v 9, no. 4, p 365-368.

Durand, A and Lang, J, 1986, Approche critique des méthodes de reconstitution paléoclimatique: le Sahel nigéro-tchadien depuis 40,000 ans: Bull Soc géol France (8), v 2, no. 2 , p $267-278$.

Eisma, D and Kalf, J, 1984, Dispersal of Zaire river suspended matter in the estuary and the Angola Basin: Netherlands Jour Sea Research, v 17, no. 2-4, p 385-411.

Folger, D W, 1970, Wind transport of land-derived mineral, biogenic, and industrial matter over the North Atlantic: Deep-Sea Research, v 17, no. 2, p 337-352.

Gasse, F, Rognon, P and Street, F A, 1980, Quaternary history of the Afar and Ethiopian Rift lakes, in Williams, M A J and Faure, H, eds, The Sahara and the Nile, Quaternary environments and prehistoric occupation in northern Africa: Rotterdam, Balkema, p 361-400.

Gasse, F, Stabell, B, van Iperen, J and Fourtanier, E, 1989, Freshwater diatom influx in intertropical Atlantic: Relationships with continental records from Africa: Quaternary Research, in press.

Hamilton, A C, 1982, Environmental history of East Africa, A study of the Quaternary: London, Academic Press, $328 \mathrm{p}$.

Hooghiemstra, H, Agwu, C O C and Beug, H-J, 1986, Pollen and spore distribution in recent marine sediments: a record of NW-African seasonal wind patterns and vegetation belts: "Meteor" Forsch-Ergebnisse, v C40, p 87-135.

Hustedt, F, 1921, Untersuchungen über die Natur der Harmattantrübe, Deutsche Überseeische Meteorologische Berichte, Bremen.

Hut, G, Ustlund, $\mathrm{H} \mathrm{G}$ and van der Borg, $\mathrm{K}, 1986$, Fast and complete $\mathrm{CO}_{2}$-to-graphite conversion for ${ }^{14} \mathrm{C}$ accelerator mass spectrometry, in Stuiver, $\mathrm{M}$ and $\mathrm{Kra}, \mathrm{R} \mathrm{S}$, eds, Internatl ${ }^{14} \mathrm{C}$ conf, 12th, Proc: Radiocarbon, v 28, no. 2, p 186-190.

Jansen, J H F, 1985, Middle and Late Quaternary carbonate production and dissolution, and paleoceanography of the eastern Angola Basin, South Atlantic Ocean, in Hsü, K J and Weissert, H J, eds, South Atlantic paleoceanography: Cambridge, Cambridge Univ Press, p 25-46.

1990, Glacial-interglacial oceanography of the southeastern Atlantic Ocean and the paleoclimate of west central Africa: Paris, ORSTOM-CICIBA, in press.

Jansen, J H F, Alderliesten C, van Bennekom, A J, van der Borg, $\mathrm{K}$ and de Jong, A F M, 1987, Terrigenous supply of ${ }^{10} \mathrm{Be}$ and dating with ${ }^{14} \mathrm{C}$ and ${ }^{10} \mathrm{Be}$ in sediments of the Angola Basin (SE Atlantic): Nuclear Instruments \& Methods, v B29, p 311-316.

Jansen, J H F, Kuijpers, A and Troelstra, S R, 1986, A mid-Brunhes climatic event: long-term changes in global atmosphere and ocean circulation: Science, $v 332$, no. 4750, p 619-622.

Jansen, J H F, van Weering, T C E, Gieles R and van Iperen, J, 1984, Middle and Late Quaternary oceanography and climatology of the Zaire-Congo fan and adjacent eastern Angola Basin: Netherlands Jour Sea Research, v 17, no. 2-4, p 201-249.

Kendall, R, 1969, An ecological history of the Lake Victoria Basin: Ecol Mon, v 39, no. 2, p 121-176.

Klein, R G, 1986, Carnivore size and Quaternary climatic change in southern Africa: Quaternary Research, v 26, no. 1, p 153-170.

Kolbe, R W, 1957, Fresh-water diatoms from Atlantic deep-sea sediments: Science, v 126, no. 3282, p 1053-1056.

Martinson, D G, Pisias, N G, Hays, J D, Imbrie, J, Moore, T C and Shackleton, N J, 1987, Age dating and the orbital theory of the ice ages: Development of a high-resolution 0 to 300,000-year chronostratigraphy: Quaternary Research, v 27, no. 1, p 1-29.

Melia, M B, 1984, The distribution and relationship between palynomorphs in aerosols and deep-sea sediments off the coast of Northwest Africa: Marine Geol, v 58, no. 3/4, p 345371.

Mikkelsen, N, 1984, Diatoms in the Zaire deep-sea fan and Pleistocene palaeoclimatic trends in the Angola Basin and west equatorial Africa: Netherlands Jour Sea Research, v 17, no. $2-4$, p 280-292.

Olausson, E, 1984, Oxygen and carbon isotope analyses of a Late Quaternary core in the Zaire (Congo) fan: Netherlands Jour Sea Research, v 17, no. 2-4, p 276-279.

Parmenter, C and Folger, D W, 1974, Eolian biogenic detritus in deep sea sediments: a possible index of equatorial ice age aridity: Science, v 185 , no. 4152, p 695-698.

Peyrot, B and Lanfranchi, R, 1984, Les oscillations morphoclimatiques récentes dans la vallée du Niari (République Populaire du Congo), in Coetzee, J A and van Zinderen Bakker, E M, Palaeoecology of Africa and the surrounding islands: Rotterdam, Balkema, p 265-281. 
Pokras, E M, 1987, Diatom record of late Quaternary climatic change in the eastern equatorial Atlantic and tropical Africa: Paleoceanography, v 2, no. 3, p 273-286.

Pokras, E M and Mix, A C, 1985, Eolian evidence for spatial variability of Late Quaternary climates in tropical Africa: Quaternary Research, v 24, no. 2, p 137-149.

Pokras, E M and Molfino, B, 1986: Oceanographic control of diatom abundances and species distributions in surface sediments of the tropical and southeast Atlantic: Marine Micropaleontol, v 10 , no. $1-3, \mathrm{p} 165-188$.

Rognon, P, 1987, Aridification and abrupt climatic events on the Saharan northern and southern margins, 20,000 y BP to present, in Berger, W H and Labeyrie, L D, eds, Abrupt climatic change: Dordrecht, Reidel, NATO ASI ser C, v 216, p 209-220.

Servant, M and Servant-Vildary, S, 1980, L'environnement Quaternaire du bassin du Tschad, in Williams, M A J and Faure, H, eds, The Sahara and the Nile, Quaternary environments and prehistoric occupation in northern Africa: Rotterdam, Balkema, p 133-162.

Stabell, B, 1986, Variations of diatom flux in the eastern equatorial Atlantic during the last 400,000 years ("Meteor" cores 13519 and 13521): Marine Geol, v 72, no. 3/4, p 305-323.

Tiercelin, J-J, Mondeguer, A, Gasse, F, Hillaire-Marcel, C, Hoffert, M, Larque, P, Ledee, V, Marestang, P, Ravenne, C, Raynaud, J-F, Thouveny, N, Vincens, A and Williamson, D, 1988, 25000 ans d'histoire hydrologique et sédimentaire du lac Tanganyika, Rift Est-africain: Acad sci [Paris] Comptes Rendus, v 307, ser II, p 1375-1382.

Tyson, P D, 1986, Climatic change and variability in southern Africa: Cape Town, Oxford Univ Press, $220 \mathrm{p}$

van der Borg, K, Alderliesten, C, Houston, C M, de Jong, A F M and van Zwol, N A, 1987, Accelerator mass spectrometry with ${ }^{14} \mathrm{C}$ and ${ }^{10} \mathrm{Be}$ in Utrecht: Nuclear Instruments \& Methods, v B29, p 143-145.

van der Gaast, S J and Jansen, J H F, 1984, Mineralogy, opal, and manganese of Middle and Late Quaternary sediments of the Zaire (Congo) deep-sea fan: origin and climatic variation: Netherlands Jour Sea Research, v 17, no. 2-4, p 313-341.

van Iperen, J M, van Weering, T C E, Jansen, J H F and van Bennekom, A J, 1987, Diatoms in surface sediments of the Zaire deep-sea fan (SE Atlantic Ocean) and their relation to overlying water masses: Netherlands Jour Sea Research, v 21, no. 3, p 203-217.

van Leeuwen, R J W, 1989, Sea-floor distribution and Late Quaternary faunal patterns of planktonic and benthic foraminifers in the Angola basin: Utrecht Micropaleontol Bull, $v$ 38 , in press.

van Weering, T C E and van Iperen, J, 1984, Fine-grained sediments of the Zaire deep-sea fan, sourthern Atlantic Ocean, in Stow, D A V and Piper, D J W, eds, Fine-grained sediments: deep water processes and facies: Oxford, Blackwell, Geol Soc Spec Pub, v 15, p 95-113.

van Zinderen Bakker, E M, 1983, The Late Quaternary history of climate and vegetation in East and southern Africa: Bothalia, v 14, no. 3\&4, p 369-375.

van Zinderen Bakker, E M and Coetzee, J A, 1988, A review of Late Quaternary pollen studies in east, central and southern Africa: Rev Palaeobot Palynol, v 55, p 155-174.

Zachariasse, W J, Schmidt, R and van Leeuwen, R J W, 1984, Distribution of foraminifera and calcareous nannoplankton in Quaternary sediments of the eastern Angola Basin in response to climatic and oceanic fluctuations: Netherlands Jour Sea Research, v 17, no. 2 4 , p 250-275. 